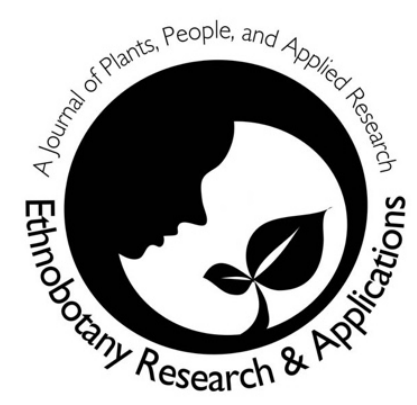

\title{
Knowledge and use of Cactaceae in rural communities in the semi- arid region of Paraíba, northeastern Brazil
}

\author{
Kamila Marques Pedrosa, Ailza Maria de Lima- \\ Nascimento, Thamires Kelly Nunes Carvalho ${ }^{3}$, Camilla \\ Marques de Lucena, Sérgio de Faria Lopes, Reinaldo \\ Farias Paiva de Lucena
}

\section{Research}

\begin{abstract}
Background: Cactaceae species are physiologically adapted to regions with arid and semi-arid climates, in which they are available and often used by traditional communities. This study aimed to analyze how ethnobotanical knowledge is influenced by socioeconomic factors such as age and gender in a semi-arid region of Paraíba, Brazil.
\end{abstract}

Methods: This study was conducted in rural communities in the semi-arid region of Paraíba, northeastern Brazil. The data were collected by applying a semi-structured questionnaire to 44 informants (30 men and 14 women). The average age of the informants was 39 years; however, women were 39-77 and men were 31-80 years old. The chi-square test was used to analyze differences regarding knowledge, according to gender and age. The influence of gender (male and female) and age in the distribution of uses per category and species was assessed through the Poisson distribution model.

Results: The following native species were recorded: Cereus jamacaru DC. subsp. jamacaru, Melocactus zehntneri, Pilosocereus gounellei (F.A.C. Weber) Byles \& G.D. Rowley subsp. gounellei, Pilosocereus pachycladus F.Ritter, Tacinga inamoena (K. Schum.) N.P. Taylor \& Stuppy, and Tacinga palmadora (Britton \& Rose) N.P. Taylor \& Stuppy, which had 436 citations in different categories of use (food, fuel, construction, fodder, medicinal, technology, and others). Our results indicated that residents cite more uses for fodder, food, and medicinal purposes. C. jamacaru had the highest UV and young men cited more uses for the species.

Conclusions: Social variables tend to influence residents' knowledge. Among the categories of use, the residents indicated a higher number of uses for fodder and $C$. jamacaru was the most prominent species.

Keywords: Ethnobotany; Caatinga; Socioeconomic Factors; Use Value

\section{Correspondence}

Kamila Marques Pedrosa ${ }^{1^{*}}$, Ailza Maria de LimaNascimento ${ }^{2}$, Thamires Kelly Nunes Carvalho ${ }^{3}$, Camilla Marques de Lucena ${ }^{4}$, Sérgio de Faria Lopes $^{1}$, Reinaldo Farias Paiva de Lucena ${ }^{3}$

${ }^{1}$ State University of Paraíba, Department of Biology, Campina Grande, Paraíba, Brazil.

${ }^{2}$ Federal University of Pernambuco, Biological Science Center, Recife, Pernambuco, Brazil.

${ }^{3}$ Federal University of Paraíba. Exact and Natural Sciences Center. Department of Systematics and Ecology. Laboratory of Ethnobiology and Environmental Sciences. Campus I. João Pessoa, Paraíba, Brazil.

${ }^{4}$ Higher Education Institute of Paraíba (IESP). Cabedelo, Paraíba, Brazil

*Corresponding Authors: rlucena@dse.ufpb.br; kamila_biopb@hotmail.com

Ethnobotany Research \& Applications 20:17 (2020) 


\section{Background}

Cactus species have been used by human populations in different regions of the world, especially in Mesoamerica, where their potential of use has been commonly recorded from several forms of use of different plant parts (Pérez-Negrón et al. 2014, Rodríguez-Arévalo et al. 2006). The socioeconomic and cultural aspects are the main factors motivating such use (Casas et al. 2002). Pieces of evidence suggest that knowledge may be influenced by environmental variations (Santoro et al. 2018) and characteristics such as gender, age, family income, time of residence, among other socioeconomic factors (Paniagua-Zambrana et al. 2014; Sousa et al. 2019).

It is common to expect that variables such as gender and age are predictors of different uses of species. However, the socioeconomic relationship may vary, depending on the approach (Sousa et al. 2019). In our study, we considered gender and age. Differences regarding gender result from how men and women use plants, based on the role played by each gender in the community (Aguilar-Santelises \& Castillo 2015). Lifelong experience among elderly people contributes to knowledge accumulation, which is not often observed among younger people (Upadhyay et al. 2010).

Mesoamerica is considered the largest center of diversity of Cactaceae species in the world, and archaeological and ethnobotanical studies have evidenced the use of these plants by traditional communities in their ancient traditions, which continue to be practiced today (Castillo \& Trujillo 1991, Mario \& Angélica 2014). In some regions of the world, the use of cacti goes beyond utilitarian purposes, attributed by traditional communities for their subsistence, supplying a demand for ornamental and landscaping market (Novoa et al. 2015).

Due to the global importance of this group of plants, which currently includes some of the most threatened species (Goettsch et al. 2015, Goettsch et al. 2019), researchers have shown an increasing interest in documenting the forms of use of cacti by traditional communities and the knowledge of these plants because of their increasing use and management (Lima-Nascimento et al. 2019, Lucena et al. 2015). This interest is justified not only by the cultural importance of the relationship between people and plants but also by the ecological importance of plants as the base of the food chain (Nóbrega et al. 2019), as well as economically when they supply the demand for resources both for subsistence and commercialization (Zappi et al. 2011).
The use of Cactaceae species in northeastern Brazil is largely due to the adverse environmental conditions caused by climatic instability, making other plant resources unavailable in the semi-arid region, such as those used as fodder (Nunes et al. 2015). Thus, ethnobotanical studies have shown that these species are resources of interest to residents of rural communities (Lima-Nascimento et al. 2017, 2019, Lucena et al. 2013, Pedrosa et al. 2018). The family Cactaceae has high morphological heterogeneity, being composed of different phytophysiognomies, such as some arboreal and shrubby species extremely adapted to arid and semiarid climates (Cruz et al. 2013) and easily found in some regions.

In rural communities in the semi-arid region of Brazil, species are usually used in different categories based on the needs of local populations. The construction of live fences and the use of plants as fodder often stand out (Lima-Nascimento et al. 2019, Lucena et al. 2013, 2015). However, other forms of use are also common such as the use of wood for energy production, ornamental, magical-religious, and food purposes, as well as the use of plant parts for distinct therapeutic treatments (Andrade et al. 2006, Lucena et al. 2014).

In addition to these diverse purposes, cacti have many intangible values, some of which vary according to the local cultural evolution but, for many species, similar uses and versatility are recurrent in different regions (Casas et al. 2014). Thus, the current use in a traditional way, in semi-arid communities, also represents the maintenance and value of the local culture in improving subsistence activities based on available resources (Lucena et al. 2015).

In ethnobotanical studies, age and gender variables are frequently analyzed because of the familiarity between women and men of a certain age group regarding some forms of use attributed to plants (Voeks 2007). It is argued that these factors are related to the transmission and maintenance of traditional knowledge because they comprise a dynamic system and a product from experiences that different people had throughout evolutionary history (Torres-Avilez et al. 2014). However, there is no standard on how socioeconomic variables influence the different uses of these species.

Based on these assumptions and through an ethnobotanical survey, our study recorded native species of the family Cactaceae and their forms of use by local human populations. Thus, we analyzed how ethnobotanical knowledge is influenced by 
socioeconomic factors such as age and gender in a semi-arid region of Paraíba, Brazil.

\section{Material and Methods}

\section{Study area characterization}

This research involved residents of the rural communities of Tapera, Caiçara, Rio Direito, and Caruatá de Dentro, located in the municipality of Cabaceiras $\left(07^{\circ} 29^{\prime} 20^{\prime \prime} \mathrm{S}\right.$ and $\left.36^{\circ} 17^{\prime} 14^{\prime \prime} \mathrm{W}\right)$, Paraíba State, northeastern Brazil (Fig. 1), $167.9 \mathrm{~km}$ from the state capital (João Pessoa). This municipality is located in the Cariri Oriental microregion and Borborema Plateau mesoregion (IBGE 2010). Cabaceiras has a population of 5,035 inhabitants, of which 2,217 live in the urban area and 2,818 in the rural area (IBGE 2010). The climate in the region is Bswh, hot semi-arid, according to the updated classification of Köeppen-Geiger (Álvares et al. 2013) and the mean annual temperature is around $26^{\circ} \mathrm{C}$, minimum averages below $20^{\circ} \mathrm{C}$, and the hottest period of the year is between November and January (Nascimento \& Alves 2008). The study area is located in a geographical region characterized by low rainfall, high solar radiation, and high desertification rate. The environmental characteristics determine a type of Seasonally Dry Tropical Forest (SDTF) with endemic biodiversity, plant species physiologically adapted to bad weather conditions (Queiroz et al. 2017).

The residents of the communities carry out agricultural and animal husbandry activities (Pedrosa et al. 2020). In communities of Caiçara and Tapera, some locals are engaged in economic activities based on rural tourism in a farm hotel located in the Tapera community (Pedrosa et al. 2020). Both communities are assisted by federal government social programs. Communities were selected due to the fact there were family ties between a researcher and the communities' residents, which contributed to greater access and reliability to obtain information from the respondents. There are 14 residences in Tapera, 6 in Caiçara, 8 in Rio Direito, and 18 in Caruatá de Dentro. It was not possible to interview all residents because some of them were sick and others were absent when researchers visited their homes.
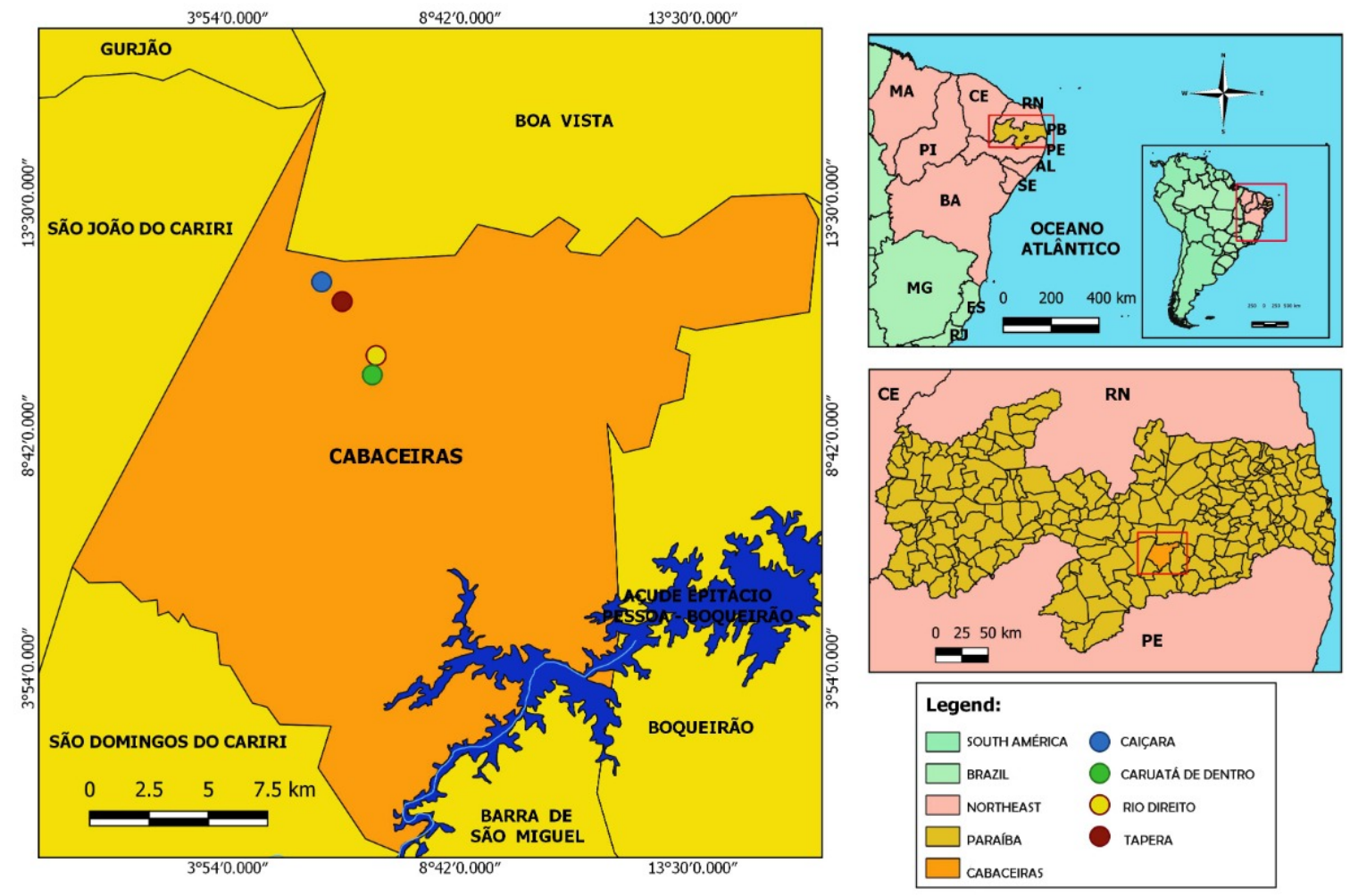

Datum: SIRGAS 2000 Projection: UTM: 24S

Fig 1. Location of the rural communities of Tapera, Caiçara, Caruatá de Dentro, and Rio Direito in the municipality of Cabaceiras (Paraíba, northeastern Brazil). (Source: Pedrosa et al. 2020). 


\section{Legal and ethical aspects}

This study was performed after being approved (CEP/HULW protocol No. 297/11) by the Health Committee's guidelines and regulations (Resolution 196/96), through the Human Ethics and Research Committee (CEP) of the Lauro Wanderley Hospital of the Federal University of Paraíba. All participants signed the Free and Informed Consent Form, allowing the publication of the obtained ethnobotanical information.

\section{Ethnobotanical data collection}

The data were collected between November 2016 and November 2018, through semi-structured interviews with the family breadwinners (men and women), focused on the knowledge and use of Cactaceae (Martin 1995). Forty-four informants (30 men and 14 women) agreed to participate in the research.

To obtain the data, the questionnaire addressed questions on socioeconomic status (name, age, gender, and occupation) and use and knowledge of Cactaceae (e.g. What cacti species do you know? Which cacti are used to produce firewood? Which ones are used for technological purpose? Which ones are used for medical purposes? Which cacti species are used for human consumption? Which ones are used as fodder? Which ones are used for veterinary purposes? Are there any other purposes these plants are used for?).

Specimens of all species cited in the interview were collected, herborized, processed, identified, and later deposited in the Herbarium Jaime Coelho de Morais of the Agricultural Sciences Center of the Federal University of Paraíba, Campus II (UFPB). The species were identified based on the specialized literature and comparing them with the herbarium specimens, as well as consulting specialists. Species collection series: $23.607,23.418,23.421$, 23.606, 23.422, and 23.419.

\section{Data Analyses}

The recorded species were classified into use categories according to the ethnobotanical literature, as follows: food, fuel, construction, fodder, medicinal, technology, and others (bioindication and ornamentation) (Lucena et al. 2012). To assess the importance of each species, a quantitative analysis was performed to calculate their use value, using the equation $U V=\Sigma U i / n$, where $U i=$ number of uses cited by each informant, $\mathrm{n}=$ total number of informants, and UV = use value of each species (Rossato et al. 1999).

The average age of the informants was 39 years; women aged from 39-77 and men aged from 31-80 years. The informants' age was categorized (with adaptations), according to the World Health Organization (WHO) (IBGE 2008), in the following classes: 1 (31-59 years), 2 (61-64), and 3 (<65 years old). The chi-square test was used to understand the differences in knowledge based on social data (age and gender). The effects of age (classes 1, 2 and 3) and gender (male and female) on the number of uses in the categories and the number of species mentioned were verified using the generalized linear model with Poisson distribution. In these analyses, age and gender were explanatory variables, whereas use citations were response variables. The Shapiro test was used to verify the normality of the variables $(p<0.05)$. All statistical analyses were performed using the Past software (version 2.17).

\section{Results}

\section{Knowledge and use of cacti species}

Six native cactus species were cited (Fig. 2), which accounted for 436 use citations. The following species were recorded: Cereus jamacaru DC. subsp. jamacaru (mandacaru) (136 citations), Pilosocereus gounellei (F.A.C. Weber) Byles \& G.D. Rowley subsp. gounellei (116 citations) (xique-xique), Pilosocereus pachycladus F.Ritter (facheiro) (93 citations), Melocactus zehntneri (Britton \& Rose) Luetzelb. (45 citations) (coroa-de-frade), Tacinga palmadora (Britton \& Rose) N.P. Taylor \& Stuppy (40 citations) (palmatória), and Tacinga inamoena (K. Schum) N.P. Taylor \& Stuppy (6 citations) (cumbeba).

The arboreal and shrub species $C$. jamacaru subsp. jamacaru (UV 3.09), P. gounellei subsp. gounellei (UV 2.63), and Pilosocereus pachycladus F.Ritter (UV 2.13) had the highest use values. The other species had values lower than 2 (Table 1). Food, fodder, and medicinal categories had the most prominent use values for all species, differing only in their useful parts and purpose of use.

The fodder category representativeness is justified by the use of cacti in "severe drought" periods, according to the informants, becoming the main source of animal feed, which is prepared by cutting and burning the cladodes which will be consumed by the animals.

Food was the second most cited category, although no consumption of fruit in natura has been recorded in the communities. In many cases, residents do not eat cactus fruit due to prejudice and/or its unpleasant texture. 

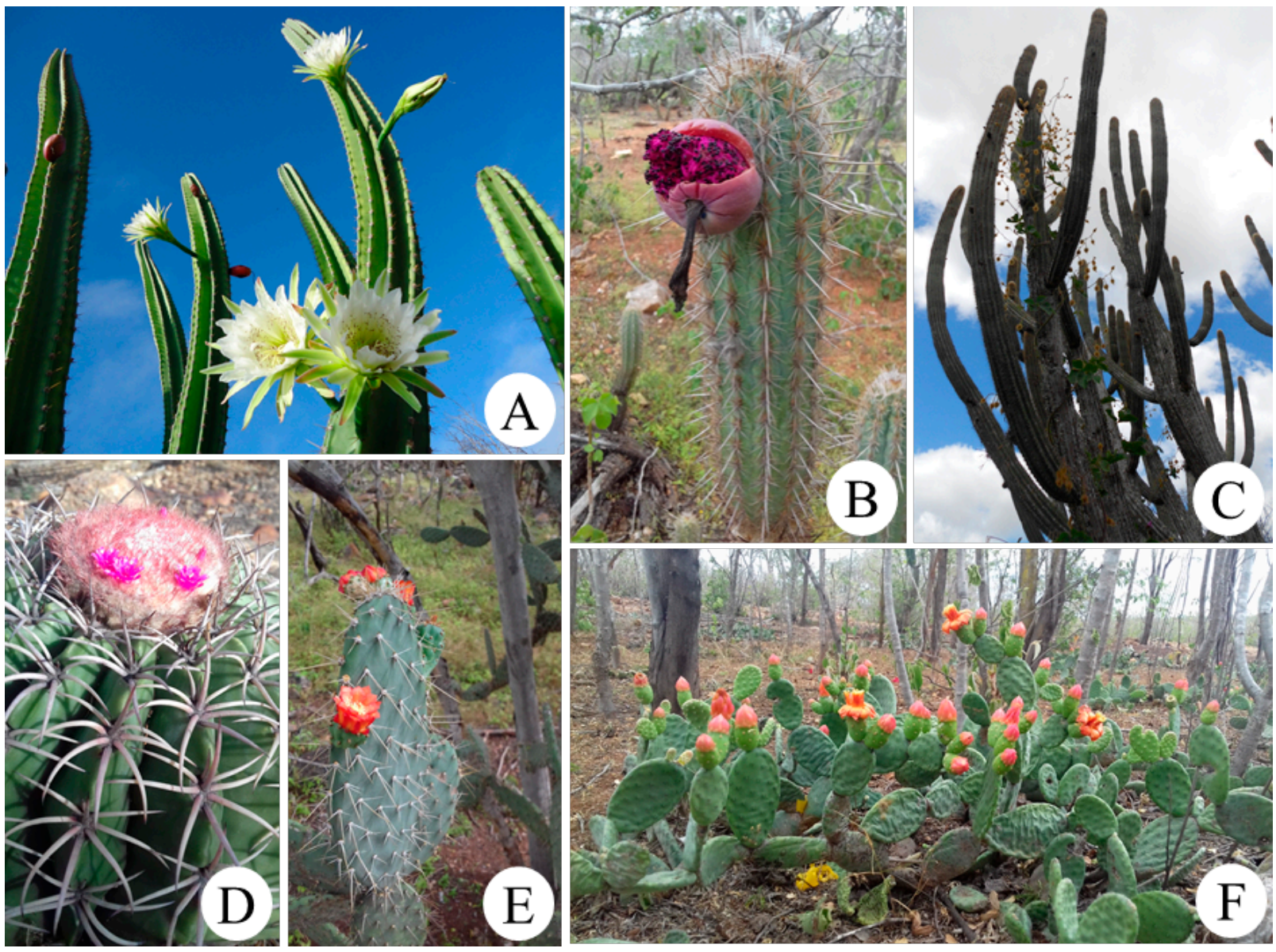

Fig 2. Native cactus species recorded in the rural communities of Caiçara, Tapera, Rio Direito, and Caruatá de Dentro in the municipality of Cabaceiras (Paraiba, northeastern Brazil). (A) Cereus jamacaru DC. subsp. jamacaru; (B) Pilosocereus gounellei (F.A.C. Weber) Byles \& G.D. Rowley subsp. gounellei; (C) Pilosocereus pachycladus F.Ritter; (D) Melocactus zehntneri (Britton \& Rose) Luetzelb; (E) Tacinga palmadora (Britton \& Rose) N.P. Taylor \& Stuppy; and (F) Tacinga inamoena (K. Schum) N.P. Taylor \& Stuppy. Photo: Kamila Pedrosa.

In the medicinal category, species were cited by the informants for therapeutic treatments. The informants indicated species to treat diseases belonging to four body systems (organized according to the World Health Organization). Undefined diseases or undefined pains (general inflammation and infection), digestive system disorder (intestinal problem), gastrointestinal system (urinary inflammation and kidney problem), respiratory system disorder (cough and shortness of breath). C. jamacaru was the species most indicated for the treatments, except for general inflammation and shortness of breath, whereas $T$. inamoena and $T$. palmadora were not indicated for treatments.

\section{Effects of social factors on knowledge}

There were differences in use citations for category and species between social factors (age and gender). Age influenced the use of species $\left(X^{2}=\right.$ $146.567 ; p<0.05)$ and the number of citations in the categories $\left(X^{2}=213.251 ; p<0.05\right) \quad($ Table 2). Regarding age, significant differences $(p=0.001)$ were observed for the age group 31-59 years), as well as a higher number of citations for food and fodder purposes (Table 4). On the other hand, elderly people (>65 years old) cited more uses for construction and technology categories. In addition, the age group 31-59 years showed a strong relationship $(p=0.001)$ for $C$. jamacaru and $P$. gounellei (Table 5).

The gender influenced the citation of species $\left(X^{2}=\right.$ $11.07 ; p<0.05)$ and categories $\left(X^{2}=15.592 ; p<0.05\right)$ (Table 3 ). Food, fodder, and medicinal categories were significant $(p=0.001)$ and most frequently mentioned by men (Table 4). There was a weak correlation between gender and fuel, construction, others, and technology categories (Table 4). T. inamoena was the only species with no significant data $(p=4232)$ (Table 5). 
Table 1. Species recorded in different use categories in the rural communities of Caiçara, Tapera, Rio Direito, and Caruatá de Dentro in the municipality of Cabaceiras (Paraíba, northeastern Brazil), followed by their voucher number, vernacular name, useful part, use value, and number of citations. Use categories: $\mathrm{Ct}=\mathrm{construction;} \mathrm{Fo} \mathrm{=} \mathrm{food;} \mathrm{Fu} \mathrm{=} \mathrm{fuel;}$ $\mathrm{Fd}=$ fodder; $\mathrm{Me}=$ medicinal; Ot = other; and Tc = technology. Useful parts: Cla = cladode; $\mathrm{Th}=$ thorn; $\mathrm{FI}=$ flower; $\mathrm{Fr}=$ fruit; $\mathrm{Wp}=$ whole plant; Ro = root; Inb = inner bark; Wo = wood; and $\mathrm{Se}=$ seed.

\begin{tabular}{|c|c|c|c|c|c|c|}
\hline Species & Voucher & Vernacular name & Uses & Useful part & UV & No. of Citations \\
\hline Cereus jamacaru DC. subsp. jamacaru & 23.607 & Cardeiro & Fo, Fd, Me, Ot, Tc & $\begin{array}{l}\text { Cla, Th, Fl, Fr, Wo, } \\
\text { Inb, Wp, Ro }\end{array}$ & 3.09 & 136 \\
\hline $\begin{array}{l}\text { Pilosocereus gounellei } \\
\text { (F.A.C. Weber) Byles \& Rowley subsp. gounellei }\end{array}$ & 23.418 & Xique-xique & Fo, Fd, Me & $\begin{array}{l}\text { Cla, Fl, Fr, Inb, Wp, } \\
\text { Ro }\end{array}$ & 2.63 & 116 \\
\hline Pilosocereus pachycladus F.Ritter & 23.421 & Facheiro & $\begin{array}{l}\text { Fo, Fu, Ct, Fd, Me, } \\
\text { Tc }\end{array}$ & $\begin{array}{l}\text { Cla, Fr, Wo, Inb, } \\
\text { Wp }\end{array}$ & 2.13 & 93 \\
\hline Melocactus zehntneri (Britton \& Rose) Luetzelb & 23.606 & Coroa-de-Frade & Fo, Fd, Me, Ot & $\begin{array}{l}\text { Cla, Fl, Fr, Inb, Wp, } \\
\text { Se }\end{array}$ & 1.02 & 45 \\
\hline $\begin{array}{l}\text { Tacinga palmadora (Britton \& Rose) N.P. Taylor \& } \\
\text { Stuppy }\end{array}$ & 23.422 & Palmatória & Fd, Ot & Cla, Fr, Wp & 0.90 & 40 \\
\hline Tacinga inamoena (K. Schum) N.P. Taylor \& Stuppy & 23.419 & Cumbeba & Fo, Fd & $\mathrm{Fr}$ & 0.25 & 6 \\
\hline
\end{tabular}

Table 2. Chi-square analysis $\left(x^{2}\right)$ for the relationship between age and knowledge of cacti in rural communities (Tapera, Caiçara, Caruatá de Dentro, and Rio Direito), Cabaceiras, Paraíba, Brazil.

\begin{tabular}{|c|c|c|c|c|c|c|c|c|c|c|}
\hline Variables & & General & $\begin{array}{l}\text { General } \\
\text { limit }\end{array}$ & Cardeiro & $\begin{array}{l}\text { Coroa- de } \\
\text { frade }\end{array}$ & Cumbeba & Facheiro & Palmatória & Xique-xique & Limit values \\
\hline & Shapiro-Wilk & 0.9335 & 0.947 & 0.9527 & 0.8792 & 0.4623 & 0.9202 & 0.8507 & 0.8924 & 0.929 \\
\hline Age-species & Chi^2 $^{\prime}$ & 96.802 & 146.567 & 1.9032 & 0.6129 & 59.425 & 1.9032 & 7.3226 & 1.3871 & 43.773 \\
\hline Age - categories & Chi^2 $^{\wedge}$ & 152.162 & 213.251 & 0.5919 & 1.036 & 0.009 & 0.917 & 0.2957 & 0.921 & 0.767 \\
\hline
\end{tabular}

Table 3. Chi-square analysis $\left(x^{2}\right)$ for the relationship between gender and use categories of cacti in rural communities (Tapera, Caiçara, Caruatá de Dentro, and Rio Direito), Cabaceiras, Paraíba, Brazil. Use categories: Fo = food; Fu = fuel; Ct = construction; Fd = fodder; Me = medicinal; Ot = other; and Tc = technology.

\begin{tabular}{|c|c|c|c|c|c|c|c|c|c|c|c|}
\hline Variables & & General & General limit & Fo. & Fu. & Ct. & Fd. & Me. & Ot. & Tc. & Limit values \\
\hline & Shapiro-Wilk & 0.9395 & 0.947 & 0.9478 & 0.2698 & 0.4778 & 0.9332 & 0.7423 & 0.57 & 0.4651 & 0.929 \\
\hline Gender-species & Chi^2 $^{\wedge}$ & 3.772 & 11.07 & 3.7097 & 15.04 & 59.452 & 3.1935 & 14.806 & 41.905 & 54.29 & 43.773 \\
\hline Gender-category & $\mathrm{Chi}^{\wedge} 2$ & 4.626 & 15.592 & 57.77 & 1.06 & 2.04 & 11.75 & 15.92 & 4.203 & 3.867 & 0.767 \\
\hline
\end{tabular}


Table 4. Poisson analysis for social variables (gender and age) related to use categories of cacti in rural communities (Tapera, Caiçara, Caruatá de Dentro, and Rio Direito), Cabaceiras, Paraíba, Brazil. Use categories: Fo = food; Fu = fuel; $\mathrm{Ct}=$ construction; Fd = fodder; $\mathrm{Me}=$ medicinal; Ot $=$ other; and $\mathrm{Tc}=$ technology.

\begin{tabular}{|c|c|c|c|c|c|c|c|c|c|c|c|c|c|c|c|}
\hline Characteristics & Variables & Fo. & $\mathbf{P}$ & $\mathrm{Fu}$ & $\mathbf{P}$ & $\mathbf{C t}$ & $\mathbf{P}$ & Fd & $\mathbf{P}$ & Me & $\mathbf{P}$ & Ot & $\mathbf{P}$ & Tc & $\mathbf{P}$ \\
\hline \multirow[t]{2}{*}{ Gender } & Women & 41 & & 1 & & 1 & & 74 & & 14 & & 3 & & 3 & \\
\hline & Men & 83 & 0.001 & 1 & 0.9196 & 5 & 0.4232 & 181 & 0.001 & 17 & 0.001 & 6 & 0.174 & 5 & 0.2381 \\
\hline \multirow[t]{6}{*}{ Age group } & $31-59$ & 81 & & 1 & & 2 & & 166 & & 19 & & 5 & & 3 & \\
\hline & 61 & 6 & & 0 & & 0 & & 15 & & 1 & & 0 & & 0 & \\
\hline & 62 & 4 & & 0 & & 0 & & 7 & & 0 & & 0 & & 0 & \\
\hline & 63 & 0 & & 0 & & 0 & & 4 & & 0 & & 0 & & 0 & \\
\hline & 64 & 0 & & 0 & & 0 & & 2 & & 0 & & 0 & & 0 & \\
\hline & $>65$ & 33 & 0.001 & 1 & 0.999 & 4 & 0.999 & 61 & 0.001 & 11 & 0.7374 & 4 & 0.999 & 5 & 0.999 \\
\hline
\end{tabular}

Table 5. Poisson analysis for social variables (gender and age) related to cacti species used in rural communities (Tapera, Caiçara, Caruatá de Dentro, and Rio Direito), Cabaceiras, Paraíba, Brazil.

\begin{tabular}{|c|c|c|c|c|c|c|c|c|c|c|c|c|c|}
\hline Characteristics & Variables & Cardeiro & $\mathbf{P}$ & $\begin{array}{l}\text { Coroa- } \\
\text { de-frade }\end{array}$ & $\mathbf{P}$ & Cumbeba & $\mathbf{P}$ & Facheiro & $\mathbf{P}$ & Palmatória & $\mathbf{P}$ & $\begin{array}{l}\text { Xique- } \\
\text { Xique }\end{array}$ & $\mathbf{P}$ \\
\hline \multirow[t]{2}{*}{ Gender } & Women & 47 & & 11 & & 2 & & 25 & & 11 & & 41 & \\
\hline & Men & 89 & 0.001 & 34 & 0.001 & 4 & 0.4232 & 68 & 0.001 & 29 & 0.001 & 74 & 0.001 \\
\hline \multirow[t]{6}{*}{ Age group } & $31-59$ & 91 & & 26 & & 2 & & 56 & & 25 & & 77 & \\
\hline & 61 & 5 & & 4 & & 0 & & 5 & & 3 & & 5 & \\
\hline & 62 & 2 & & 2 & & 0 & & 3 & & 1 & & 3 & \\
\hline & 63 & 1 & & 0 & & 0 & & 0 & & 1 & & 2 & \\
\hline & 64 & 1 & & 0 & & 4 & & 0 & & 0 & & 1 & \\
\hline & $>65$ & 36 & 0.001 & 13 & 0.3781 & 4 & 0.9999 & 29 & 0.001 & 10 & 0.5004 & 27 & 0.001 \\
\hline
\end{tabular}




\section{Discussion}

\section{Knowledge and use of Cactaceae species}

The species cited by the respondents are commonly and frequently listed in floristic or ethnobotanical studies in northeastern Brazil (Coelho et al. 2015, Lima-Nascimento et al. 2019, Lucena et al. 2015, Santos \& Meiado 2015). These genera occur in areas of greater climatic seasonality, where they have higher densities of specimens and are little influenced by environmental variations (Santos 2009). Some of these species share the same geographic distributions in the semi-arid region of Brazil, such as C. jamacaru subsp. jamacaru, an arboreal columnar cactus, and $P$. gounellei subsp. gounellei, a shrub-size plant, both found in the different phytophysiognomies of the region (Menezes et al. 2013).

The six species are used differently (multiple uses). Three species ( $P$. pachycladus, $C$. jamacaru and $M$. zehntneri) stood out, which can be justified by their versatility of use. Versatility corresponds to the different types of use of a species by human groups (Albuquerque \& Oliveira 2007). Possibly, the amount of information related to the cactaceae species may result in a lower pressure of use on other species. However, availability and current use of these species must be investigated to understand the nuances concerning these assumptions.

However, C. jamacaru had the highest use value, corroborating studies conducted in other semiarid regions of Brazil (Lima-Nascimento et al. 2019, Lucena et al. 2015). C. jamacaru is an important species for residents. This can be explained due to its frequent use as fodder and morphological characteristics that contributes to an easy handling (Carvalho et al. 2019, Lucena et al. 2015). Furthermore, the local importance of this species has led residents to maintain in situ management practices as they cultivate agricultural fields (Pedrosa et al. 2020).

The informants indicate cacti species for human consumption. However, while they talked about the uses, they explained that the habit of consuming such species was common in the past. In many cases, residents do not eat cactus fruit due to prejudice and/or its unpleasant texture (Lucena et al. 2017). Nevertheless, its consumption in other regions is considered to be an emergency (Chaves \& Barros 2015) and may be associated with the nutritional quantities available for people (Lucena et al. 2015, Machado et al. 2018).
Medicinal was the third most cited category, mainly by men, differing from other ethnobotanical studies, in which women tend to use more plants to treat diseases than men (Aguilar-Santelises \& Castillo 2015). There is few information on medicinal use of cacti in comparison with other categories; however, this practice has been recorded in other regions of Brazil (Agra et al. 2007, Bravo-Filho et al. 2018, Costa-Neto \& Moraes 2000, Lucena et al. 2012, 2014, 2015, Lima-Nascimento et al. 2017, 2019, Ribeiro et al. 2014. Pharmacological trials have evidenced the efficacy of native Cactaceae species used by local populations, such as $C$. jamacaru subsp. jamacaru, which is useful for the treatment of kidney diseases (Tourinho 2000), in addition to containing natural substances used to obtain antibiotics (Davet et al. 2009). In the state of Paraíba, Lucena et al. (2013), Cavalcante \& Resende (2007) recorded the use of $M$. zehntneri for the treatment of respiratory problems. The pharmacological characteristics of these species indicate the relevance of medicinal knowledge for future bioprospecting studies.

\section{Effect of social factors on knowledge of Cactaceae}

Our analyses revealed a relationship between social factors (age and gender) and residents' knowledge. These are important influences that can assist in understanding the dynamics of local traditional knowledge. There is little attention in the literature to the way these variables influence the use of cacti in the semi-arid region of Brazil (Lucena et al. 2012). Nevertheless, in recent years, some studies have focused on the influence of socioeconomic factors (age, gender, income, time of residence) in the knowledge of plants for different purposes (Aguilar-Santelises \& Castillo 2015, Arruda et al. 2019, PaniaguaZambrana et al. 2014, Sousa et al. 2019) and of cacti in Mexico (Blancas et al. 2013).

Our results showed that men cite more cacti species. This can be associated with two factors: (1) there was a higher number of men participating in the research than women and (2) the frequency of citation in fodder category, as men tend to use these plants more often to feed domestic animals.

The use of cacti for fodder production is a current practice in the semi-arid region of Brazil, mainly through rudimentary techniques such as burning cladodes in periods of "severe drought" (Lucena et al. 2015, Pedrosa et al. 2020). Probably, this practice is rarely performed by the women participating in this study, and it is possible they 
have indicated little information on cacti due to limitation in agricultural practices. It has been evidenced that women's knowledge may be limited by the type of activity, resulting in lesser knowledge of native species in comparison with men (Sousa et al. 2019).

Younger residents cited more use categories. This can be related to the frequency of young men in field activities and the possibility of using cacti as fodder. This information corroborates the results by Sousa et al. (2019) who observed that younger people cited more species because, economically, these plants are related to generation of income and acquisition of goods. However, from the data recorded in our research, it is not possible to say there is a relationship between young men's income and the collection of species, due to the lack of economic factors.

The way of life of older people may have related to the lower frequency of citation in certain categories, although categories such as domestic construction and production of technological artifacts are more representative among older people. Thus, it is believed that a greater contact with cacti over time may have led older people to cite timber uses, given that the characteristics of wood vary with the plant size (Reyes-Rivera et al. 2015).

\section{Conclusions}

Our results showed that age and gender tend to influence local knowledge. The cacti species are mainly used to feed domestic animals. Moreover, people often mention C. jamacaru for all uses, especially for fodder purpose. Therefore, in addition to socioeconomic characteristics, environmental parameters must be considered because the age group is often associated with time and environmental changes in a region.

\section{List of abbreviations:}

List of abbreviations: CEP/HULW: Human Ethics and Research Committee / Lauro Wanderley Hospital of the Federal University of Paraíba.

Ethics approval and consent to participate: The purpose of the study was explained to the community members interviewed, and they were asked to sign an informed consent form, as required by the Brazilian National Health Council through the Research Ethics Committee (Resolution 510/2016). The study is part of a larger project entitled Identification of Patterns of Use of Native Species in Caatinga Areas: An Ethnobiological and Conservationist Approach, which has already been approved by the Human
Research Ethics Committee (CEP, for its initials in Portuguese) of the Lauro Wanderley Hospital, Federal University of Paraíba, registered under protocol CEP/HULW no. 297/11 (with cover sheet no. 420134).

Consent for publication: Not applicable.

Availability of data and materials: N/A. The data was not deposited in public repositories.

Competing interests: The authors declare that they have no competing interest.

Funding: The CAPES (Coordination for the Improvement of Higher Education Personnel) for granting a master's scholarship to the first author. Authors' contributions: K.M.P and R.F.P.L conceptualized the study, designed the methods, conducted the ethnobotanical survey, analyzed the data and drafted the manuscript. A.M.L.N, T.K.N.C., C.M.L. and S.F.L. conceptualized the idea of this manuscript and participated in reviewing the manuscript. Both authors read and approved the final manuscript.

\section{Acknowledgements}

The authors thank the informants of the study rural communities for their participation in the research, the professor Leonardo Pessoa Félix (CCA/UFPB) for the species identification; Arliston Pereira for contributions to statistical analysis.

\section{Literature cited}

Agra MF, Baracho GS, Basílio IJD, Nurit K, Coelho VP, Barboza DA. 2007. Sinopse da flora medicinal do Cariri Paraibano. Oecologia Brasiliensis 3: 323-330.

Aguilar-Santelises R, Del-Castillo RF. 2015. Demographic and Socio-Economic determinants of tradiotional plant knowledge among the Mixtecs of Oaxaca, Southern Mexico. Human Ecology 45: 655-667

Albuquerque UP, Oliveira RF. 2007. Is the useimpact on native caatinga species in Brazil reduced by the Hugh species richness of medicinal plants? Journal of Ethnopharmacology 113: 156-170.

Alvares CA, Stape JL, Sentelhas PC, Gonçalves JL, Sparovek G. 2013. Mapa de classificação climática de Köppen para o Brasil. Meteorologische Zeitschrift 6: 711-728.

Andrade CTS, Marques JGW, Zappi DC. 2006. Utilização medicinal de cactáceas por sertanejos Baianos. Revista Brasileira de Plantas Medicinais Botucatu 3: 36-42 
Arruda HLS, Santos JFO, Albuquerque UP, Alves M. 2019. Influence of Socioeconomic Factors on the Knowledge and Consumption of Firewood in the Atlantic Forest of Northeast Brazil. Economic Botany 1: 1-12.

Blancas J, Casas A, Pérez-Salicrup D, Caballero J, Vega E. 2013. Ecological and socio-cultural factors influencing plant management in Náhuatl communities of the Tehuacán Valley, Mexico. Journal of Ethnobiology and Ethnomedicine 39: 2-22.

Bravo-Filho ES, Santana MC, Santos PAA, Ribeiro AS. 2018. Levantamento etnobotânico da família Cactaceae no estado de Sergipe. Revista Fitos 1: 41-53.

Casas A. 2002. Uso y Manejo de cactáceas Columnares Mesoamericanas. CONABIO, Biodiversitas 40: 18-23.

Casas A, Camou A, Otero-Arnaiz A, Rangellanda S, Cruse-Sanders J, Solís L, Torres I, Delgado A, Moreno-Calles AI, Vallejo M, Guillén S, Blancas J, Parra F, Farfán-Heredia B, AguirreDugua X, Arellanes Y, Pérez-negrón E. 2014. Manejo tradicional de biodiversidad $y$ ecosistemas em Mesoamerica: the Tehuacan Valley. Investigación ambiental 2: 23-44.

Carvalho TKN, Lucena CM, Lima JRF, Cruz DD, Lucena RFP. 2019. Local botanical knowledge of cacti in the semiarid region of Paraíba, northeastern Brazil. Ethnobotany Research and Applications 42: 1-11.

Castillo RF, Trujillo S. 1991. Ethnobotany of Ferocactus histrix and Echinocactus platyacanthus (Cactaceae) in the semiarid Central Mexico: Past, Present and future. Economic Botany 45: 495-502.

Cavalcanti NB, Resende GM. 2007. Efeito de diferentes substratos no desenvolvimento de mandacaru (Cereus jamacaru P. DC.), facheiro (Pilosocereus pachycladus Ritter), xiquexique (Pilosocereus gounelli (A, Webwr ex K. Schum.) Bly. ex Rowl.) e coroa-de-frade (Melocactus bahiensis Britton \& Rose). Revista Caatinga 1: 28-35.

Chaves EMF, Barros RFM. 2015. Cactáceas: recurso alimentar emergencial no semiárido, Nordeste do Brasil. Gaia Scientia 2: 129-135.

Coelho PJA, Junior SCFF, Nascimento E. 2015. Coleta e conservação ex situ de cactáceas nativas do Estado do Ceará. Gaia Scientia 2: 183-192.
Costa-Neto E, Moraes V. 2000. The use of medicinal plants in the Country of Tanquinho, State of Bahia, Northeastern, Brazil. Revista Brasileira de Plantas Medicinais 2: 1-8.

Cruz MP, Peroni N, Albuquerque UP. 2013. Knowledge, use and management of native wild edible plants from a seasonal dry forest (NE, Brazil). Journal of Ethnobiology and Ethnomedicine 9: 1-20.

Davet A, Virtuoso S, Dias JFG, Miguel MD, Oliveira AB, Miguel OG. 2009. Atividade antibacteriana de Cereus jamacaru DC, Cactaceae. Revista Brasileira de Farmacognosia Brazilian Journal of Pharmacognos 2: 561-564.

Goettsch B, Hilton-Taylor C, Cruz-Piñón G, Duff $J$, Frances $A$, Hernández $H$, Inger R, Pollock $C$, Schipper J, Superina M, Taylor N, Tognollei M, Abba A, Arias S, Arreola-Nava H, Baker M, Barcenas R, Barrios D, Braun P, Gaston K. 2015. High proportion of cactus species threatened with extinction. Nature Plants 10: 15142.

Goettsch B, Durán AP, Gaston KJ. 2019. Global gap analysis of cactus species and priority sites for their conservation. Conservation Biology 2: 369-376.

IBGE. 2008. Antropometria e dados de classes de idade. Disponível em: http://www.ibge.gov.br/home/estatistica/populac ao/condicaodevida/pof/2008_2009_encaa/ defaulttabzip_prev.shtm. Accessed 12 mar 2013.

IBGE. 2010. (Instituto Brasileiro de Geografia e Estatística). Disponível em: http://censo2010.ibge.gov.br. Accessed 03 may 2018

Lima-Nascimento AM, Bento-Silva JS, Ferraz EMN. 2017. Knowledge and use of caatinga plants by local farmers living in a rural community in the municipality Pesqueira. Cientec 1: 10-23.

Lima-Nascimento AM, Bento-Silva JS, Lucena CM, Lucena RFP. 2019. Ethnobotany of native cacti in the Northeast Region of Brazil: can traditional use influence availability? Acta Botanica Brasilica 2.

Lucena CM, Costa GC, Silva GG, Carvalho TKNC, Guerra NM, Quirino ZGM, Lucena RFP. 2012. Uso e conhecimento de cactáceas no município de São Mamede (Paraíba, Nordeste do Brasil). Revista de Biologia e Farmácia volume especial:121-34.

Lucena CM, Lucena RFP, Costa, GM, Carvalho TKNC, Silva GG, Alves RRN, Pereira DD, Ribeiro JRS, Alves CAB, Quirino ZGM, Nunes EN. 2013. 
Uso e conhecimento de Cactaceae no Nordeste do Brasil. Jounal Ethnobiology Ethnomedicine 9: 62.

Lucena CM, Carvalho TKN, Marin EA, Nunes EM, Oliveira RS, Melo JG, Casas A,vLucena RFP. 2014. Potencial medicinal de cactáceas en la región semiárida del Nordeste de Brasil. Gaia Scientia (UFPB) 1: 36-50.

Lucena CM, Carvalho TKN, Ribeiro JES, Quirino ZGM, Casas A, Lucena RFP. 2015. Conhecimento botânico tradicional sobre cactáceas no semiárido do Brasil. Gaia Scientia (UFPB) 9: 77.

Lucena RFP, Lucena CM, Meiado MV, Cruz DD, Andrade MO, Casas A. 2017. Uso, manejo y domesticación de cactáceas en Brasil. In: Casas A, TorresGuevara J, Parra F (eds) Domesticación en el continente americano. Investigación para el manejo sustentable de recursos genéticos en el Nuevo Mundo. 1ed.México: Editorial Morevalladolid.

Machado JS, Lucena CM, Santos SS, Ferreira EC, Nunes GM, Lucena RFP. 2018. Conhecimento botânico local sobre cactáceas: um estudo de caso no município de Boqueirão, Paraíba, Nordeste do Brasil. Flovet 10: 1-21.

Mario M, Angélica M. 2014. El cactus San Pedro ayer y hoy. Um enfoque etnobotánico. Cactáceas y suculentas Mexicanas 4: 121-155.

Martin GJ. 1995. Etnobotânica: um manual de métodos. London, Chapman Hall.

Menezes MOT, Taylor NP, Loiola MIB. 2013. Flora do Ceará, Brasil: Cactaceae. Rodriguesia 4: 757-774.

Nascimento SS, Alves JJA. 2008. Ecoclimatologia do Cariri Paraibano. Revista Geográfica Acadêmica 3: 28-41.

Nóbrega GVG, Valiente-Banuet A, Araujo AC. 2019. Reproductive phenology of cacti species in the Brazilian Chaco. Journal of Arid Environments161: 85-93.

Novoa A, Roux JJ, Robertson MP, Wilson JRU, Richardson DM. 2015. Introduced and invasive cactus species: A global review. AoB Plants 7: 114.

Nunes AT, Lucena RFP, Ferreira-Santos MV, Albuquerque UP. 2015. Local knowledge about fodder plants in the semi-arid region of Northeastern Brazil. Journal of Ethnobiology and Ethnomedicine 11: 12.
Paniagua-Zambrana NY, Camara-Lerét R, Bussmann RW, Macía MJ. 2014. The influence of socioeconomic factors on traditional knowledge: a cross scale comparison of palm use in northwestern South America. Ecology and Society 4: 1-21.

Pedrosa KM, Lucena CM, Lucena RFP, Lopes SFL. 2018. Traditional Techniques for the Management of Cactaceae in the Americas: The relationship between use and conservation. Ethnobiology Leers 2: 276-282.

Pedrosa KM, Lopes SF, Carvalho TKN, Lucena CM, Lima-Nascimento AL, Lucena RF. 2020. Traditional management of cactaceae by local populations in the semi-arid region of Brazil. Ethnobiology and Conservation 9: 28.

Pérez-Negrón E, Dávila P, Casas A. 2014. Use of columnar cacti in the Tehuacán Valley, Mexico: Perspectives for sustainable management of non-timber forest products. Journal of ethnobiology and ethnomedicine 1: 79.

Queiroz LP, Cardoso D, Fernandes MF, Moro MF. 2017. Biodiversity 2 Diversity and Evolution of Flowering Plants o the Caatinga Domain. In: Silva JMC, Leal IR, Tabarelli M (eds). Caatinga: The Largest Tropical dry forest region in South America. Springer International Publishing (ebook), Cham, Switzerland.

Reyes-Rivera J, Canché-Escamilla G, SotoHernándesz M, Terrazas. 2015. Correction: Wood Chemical composition in Species of cactaceae: The Relationship between lignification and stem morphology. Plos One 10:6

Ribeiro DA, Oliveira LGS, Macêdo DG, Menezes IRA, Costa JGM, Silva MAP, Lacerda SR, Souza MM. Souza. 2014. Promising medicinal plants for bioprospection in a Cerrado area of Chapada do Araripe, Northeastern Brazil. Journal of Ethnopharmacology 3: 1522-1533.

Rodríguez-Arévalo I, Casas A, Lira R, Campos J. 2006. Uso, Manejo y procesos de domesticación de em el Valle de Tehuacán-Cuicatlán, México. Interciencia 31: 677-685.

Rossato SC, Leitão-Filho H, Begossi A. 1999. Ethnobotany of Caiçaras of the Atlantic Forest Coast (Brazil). Economic Botany 53: 387-395.

Santos CS, Meiado MV. 2015. Levantamento florístico e status de conservação dos cactos do estado de Sergipe Nordeste do Brasil. Gaia Scientia 2: 136-146.

Santos MR. 2009. Influência de variáveis ambientais e espaciais na distribuição geográfica 
da família Cactaceae no Leste do Brasil. Dissertação de Mestrado. Universidade Federal de Lavras, Lavras, Brasil.

Santoro FR, Nascimento ALB, Soldati GT, Ferreira-Junior WS, Albuquerque UP. 2018. Evolutionary ethnobiology and cultural evolution: opportunities for research and dialog. Jounal of ethnobiology and ethnomedicine 14: 1-14.

Sousa RS, Medeiros PM, Albuquerque UP. 2019. Can socioeconomic factors explain the local importance of cultural plants in a socioecological system? Acta Botanica Brasilica.2: 283-291.

Torres-Avilez W, Nascimento ALB, Campos LZO, Silva FS, Albuquerque UP. 2014. Fatores que afetam o conhecimento biológico tradicional. ed. Albuquerque UP. Introdução a etnobiologia. NUPEEA, Recife, Pernambuco, Brasil.
Tourinho MJ. 2000. Abordagem etnofarmacológica das plantas medicinais diuréticas no povoado de Capim Grosso, município de Canindé de São Francisco, Sergipe. Curitiba 1: 34-47.

Upadhyay B, Dhaker AK, Kumar A. 2010. Ethnomedicinal and ethnopharmaco-statistical studies of Eastern Rajasthan, India. Journal Ethnpharmacology 129: 64-68

Voeks RA. 2007. Are women reservoirs of traditional plant knowledge? Gender, ethnobotany and globalization in northeast Brazil. Singapore Journal of Tropical Geography 1: 7-20.

Zappi D, Taylor N, Ribeiro-Silva S. 2011. Plano de ação nacional para a conservação das Cactáceas. Brasília, ICMBIO. 